\section{The Novelty of the Ethics of Samuel Richardson's Novels through Wittgenstein's Lenses}

\section{Anca Raluca PURCARU1 \\ ${ }^{1}$ Apollonia University, Iasi, România, ralu pur@yahoo.com}

\begin{abstract}
In the puritan and utilitarian environment of 18th century England, there is a literary trend called sentimentalism, which stands out as an attitude of opposition towards aristocratic morality. The characteristics of the trend are the cult of feelings, the cult of nature (as an unspoiled environment) and the proclamation of puritan morality. The initiator of this trend was Samuel Richardson, who adopts the genre of the epistolary novel and writes Pamela (1740) and Clarissa Harlowe (1747-1748). If the first is based on the theory of rewarded virtue, the second one presents the punishment of vice. Together with other realistic novelists of his century, Richardson wanted to present heroes from the bourgeois world superior to moral representatives of the aristocracy.
\end{abstract}

Keywords: Samuel Richardson; ethics in novels; the novel Pamela; the novel Clarisa Harlowe;

How to cite: Purcaru, A. R. (2018). The Novelty of the Ethics of Samuel Richardson's Novels through

Wittgenstein's Lenses. Journal for Social Media Inquiry, 1(1), 16-22. https://doi.org/10.18662/jsmi/03 

In mediul puritan şi utilitarist al Angliei secolului al XVIII-lea, apare un curent literar numit sentimentalism, care se remarcă drept atitudine de opoziție față de morala aristocrată. Caracteristicile curentului sunt cultul sentimentului, cultul naturii (ca mediu neviciat) şi proclamarea moralei puritane. Inițiatorul acestui curent a fost Samuel Richardson, care adoptă genul romanului epistolar şi scrie Pamela (1740) şi Clarissa Harlowe (17471748). Dacă primul se bazează pe teza virtuții răsplătite, cel de al doilea prezintă viciul pedepsit. Alături de ceilalți romancieri realişti ai secolului său, Richardson dorea să prezinte eroi din lumea burgheză superiori sub raport moral reprezentanților aristocrației.

În romanul de debut, Pamela (2003), tema este cea a virtuții răsplătite, dar avem şi multe aspecte precursorii eticii feministe.

Pamela Andrews lucrează pentru o doamnă respectată din înalta societate londoneză. După moartea acesteia, deşi are doar şaisprezece ani, fiul doamnei începe să îi facă o serie de avansuri violente, iar Pamela se vede nevoită, pentru a-şi păstra virtutea, să se întoarcă în casa părinților săi, după o tentativă de viol de la care o salvează o doamna Jervis, o altă angajată a Stăpânului, aşa cum îl va numi Pamela în toate scrisorile din acest roman epistolar. Însă, în loc să fie condusă la casa părinților săi, Pamela este răpită şi dusă la moşia stăpânului său, unde trebuie să îndure abuzurile doamnei Jewkes, o servitoare care ascultă orbeşte de stăpânul său, în ciuda tuturor principiilor etice pe care sarcinile ei le încalcă. Toți cei care încearcă să o ajute pe Pamela să evadeze sunt pedepsiți, atât doamna Jervis din fosta casă, cât şi un pastor, domnul Williams, pe care stăpânul său îl bagă în închisoare. Pamela are singură o tentativă de evadare care eşuează, cochetează chiar cu ideea suicidului prin înecarea în iazul moşiei (scopul fiind de a-şi păstra virtutea intactă), idee pe care până la urmă o respinge, ajungând la concluzia că mai bine îşi lasă viaţa în voia divinităţii.

Stăpânul său se hotărăşte după această tentativă să se mute la moşia respectivă pentru a o avea pe Pamela. Incearcă o serie de metode, de la amenințări şi violențe la mituire - î propune inclusiv un contract avantajos financiar pentru ca fata să devină amanta lui. Pentru Pamela, cel mai important lucru este onoarea ei, nu bogăţia acestei lumi. Fără virtute, nu vede sensul nici unei posesii de ordin material, virtutea este bogăția şi podoaba ei, fără virtute, bijuteriile lumeşti ar evidenția tocmai lipsa acesteia, aşa că Pamela respinge cu hotărâre orice propunere, deşi este ameninţată că îşi va pierde virtutea chiar dacă nu de bunăvoie, şi va îndura şi oprobiul public, deoarece deja se crede despre dânsa că nu avea cum să îşi fi păstrat virtutea. Stăpânul său are încă o tentativă de viol, încurajat de către doamna Jewkes, dar la care renunță singur, sub influența crizei în care cade Pamela, 
speriat că aceasta va muri. Decide atunci să o ceară de nevastă, dar aceasta refuză şi această propunere, din cauza diferențelor de statut social.

In cele din urmă o eliberează, dar se îmbolnăveşte de această dată el de dor şi o roagă pe Pamela să se întoarcă la el. Deoarece Pamela este îndrăgostită de el şi crede în intențiile sale onorabile, se întoarce şi acceptă să se căsătorească cu el. $\mathrm{O}$ iartă pe doamna Jewkes, îi reintituie în drepturi pe doamna Jervis şi pe pastorul Williams, şi chiar mediază conflictul între stăpânul său şi sora acestuia, a cărei maltratări îi căzuse victimă. Mai mult, îl convinge pe soțul său să o ia în locuință pe fiica sa ilegitimă, pe care o tratează ca pe propriul copil. Noul statut de stăpână a casei nu face decât să îi ofere prilejul Pamelei să îşi dovedească onoarea şi virtutea de care deja dăduse dovadă până atunci. Soțul său este complet reformat de către Pamela, dând şi acesta dovadă de virtute.

Temele de ordin etic ale acestui roman sunt virtutea, datoria vieții de zi cu zi, credința în divinitate, decența, onoarea, demnitatea, precum şi alte calități nobile. Temele sociale ale romanului se referă la puterea pe care o are angajatorul asupra angajaților săi, care îl consideră un stăpân pe care trebuie să îl asculte orbeşte, uitând prioritatea datoriilor mai înalte de ordin etic, precum şi condiţia femeii în acele timpuri în care hărţuirea sexuală era aproape un drept al stăpânului, iar după ce acesta obținea ce îşi dorea pe plan sexual, cea care cădea victima oprobiului public era tot femeia abuzată. Posibilităţile de alegere a unei femei în Anglia secolului respectiv erau limitate.

Din fericire, ca şi eroina următorului roman, Pamela nu face compromisuri în privinţa virtuții sale, pe care şi-o apără împotriva încercărilor de corupere prin mită sau agresiune. Absolut nimic nu o poate determina pe aceasta să se dezică de principiile sale de ordin etic, iar în această rezistență la corupere şi în idealul de a nu îşi vinde trupul rezidă actualitatea romanului. Deşi receptată iniţial ca „pornografie deghizată”, cartea rămâne o luptă a unei tinere servitoare împotriva tuturor încercărilor stăpânului său prădător de a o seduce, precum şi un studiu detaliat asupra abuzului de putere în acele timpuri, abuz valabil şi astăzi. Desigur, Pamela este şi un roman optimist, având un final fericit, motivant pentru lupta pentru onoare, dar acesta nu este cazul următorului roman.

Romanul Clarissa Harlowe or The Story of Young Lady e considerat opera de căpătâi a lui Richardson (2004) şi s-a bucurat de un imens succes pe continent. De această dată protagonista este o domnişoară de condiţie înaltă.

Tânăra nobilă Clarissa este tiranizată de tatăl, fratele şi sora sa şi urmează să fie măritată împotriva voinței sale. O căsătorie aranjată în care nu îşi iubeşte soțul ar fi de neacceptat pentru tânăra care are o morală fermă. Ca 
şi în romanul precedent, eforturile sale de a-şi argumenta cu măiestrie principiile etice rămân fără ecou. Ceea ce nu știe Clarissa este Roger Holms, viitorul soţ, a fost propus printr-un complot de către nobilul Robert Lovelace. Nobilul a curtat-o pe Clarissa, dar aceasta nu l-a acceptat datorită moravurilor uşoare ale acestuia şi, în plus, a căzut victima invidiei surorii sale, datorită pasiunii pe care i-a stârnit-o acestui nobil care nu o considera eligibila pe sora Clarissei. Pentru a scăpa de căsătoria nedorită, Clarissa se gândeşte iniţial să îi accepte ajutorul lui Lovelace şi acceptă o întâlnire cu acesta, la care ajunge însă să vină numai pentru a-i comunica faptul că s-a răzgândit. Atunci Lovelace se vede nevoit să o păcălească pentru a o lua cu el, spunându-i că întâlnirea lor clandestină a fost descoperită şi Clarissa îl însoțeşte pentru a evita atât un scandal, cât şi o vărsare de sânge, propunându-şi să ofere mai târziu explicațiile exonerante. Nu se întâmplă aşa, căci în curând toată societatea va crede că a fugit cu Lovelace devenind amanta sa.

Planul lui Lovelace este să o corupă pe Clarissa, să o seducă, conform ideii că dacă îi va ceda o dată, îi va ceda mereu. Nobilul nu crede în sinceritatea principiilor puritane ale nici unei femei. Între cei doi se dă o bătălie a principiilor, Lovelace îndârjindu-se să dovedească faptul că nu poate fi sinceră. Dacă ea ar fi fost umilă şi i-ar fi cerut să îi fie cruțată virtutea, el ar fi arătat clemență, dar Clarissa îl provoacă prin virtutea de care aparent dă dovadă să îi demonstreze ipocrizia feminină. În ciuda manipulărilor lui Lovelace, Clarissa nu îi cedează, nici măcar pentru că deja a căzut în dizgrație. Lovelace încearcă să abuzeze de ea, dar planurile sale în acest sens eşuează, deoarece o dată Clarissa îl înduplecă, apoi îl amenință cu suicidul, preferând moartea dezonoarei. În ciuda tuturor maşinațiunilor lui Lovelace, în ciuda chiar a sentimentelor sale, Clarissa rămâne onorabilă. Mai mult, îi şi oferă îngrijiri lui Lovelace când acesta cade pradă bolii, arătând compasiune față de asupritor şi chiar frică pentru viaţa acestuia, deoarece deja se îndrăgostise de el. Lovelace se gândeşte la un ultim subterfugiu, şi anume să o facă pe Clarissa să creadă că şi-a pierdut onoarea faţă de un străin pentru ca, odată ce dragostea lor s-a consumat, ea să îi cedeze, fiind bucuroasă chiar că a fost vorba despre el şi nu despre altcineva. Dar o criză a Clarissei care era cât pe ce să îi curme viața îi dejoacă planurile.

Încercând din răsputeri să îşi repare reputația distrusă, nu reuşeşte. Respinsă de propria ei familie care nu o crede, victimă a dizgrației publice şi cu sănătatea şubredă de la atâtea încercări ale virtuții sale, Clarissa decide să nu mai trăiască şi îşi pregăteşte toate cele necesare înmormântării. Lovelace, căindu-se pentru faptele sale, înţelege că Clarissa e cu adevărat incoruptibilă, că nici distrugerea reputației sale nu a făcut-o să devină o fiinţă decăzută, o 
cere în căsătorie. Pentru a câştiga timp şi pentru a-l ține pe acesta la distanţă, ea recurge la un vicleşug - îi scrie că vor relua discuția când va fi în casa Tatălui ei, ea referindu-se la cel ceresc. Suferinţa îi curmă Clarissei viaţa în scurt timp, lăsându-l pe Lovelace cuprins de disperare şi durere.

După moartea Clarissei, un văr îndepărtat pe nume Morden o răzbună, ucigându-l în duel pe Lovelace. Celelalte personaje negative îşi găsesc şi ele pedeapsa, rudele Clarissei şi complicii lui Lovelace.

Faţă de Pamela, chinurile şi încercările Clarisei sunt mai elaborate şi de mai lungă durată, Clarissa fiind singură şi în propria familie în ceea ce priveşte valorile sale, faţă de Pamela, ai cărei părinți gândeau la fel ca ea. Personajul masculin, ispititorul, este de această dată mai clar conturat, prin scrisorile pe care acesta le redactează. Chimia dintre cei doi protagonişti este mai intensă, aspectul sentimental dând greutate disputelor de ordin etic. Atât Clarissa, cât şi Lovelace trebuie să lupte şi cu propriile sentimente pentru a-şi menține principiile şi ambii sunt personaje puternice. Povestea Clarissei este un exemplu al rezistenței împotriva manipulării şi un exemplu de incoruptibilitate. Clarissa reuşeşte un proces de construcție de sine pe baza unui sistem ferm de valori care o face să fie complet independentă de lumea înconjurătoare şi de evenimentele contingente care au loc în viaţa ei. Deşi nu are nici o putere asupra a ceea ce se întâmplă, Clarissa are o morală ireproşabilă şi un comportament care urmează întocmai morala sa. Sistemul său de valori nu este coruptibil şi nu se schimbă, în ciuda tuturor manipulărilor lui Lovelace sau ale familiei sale. Clarissa nu poate fi constrânsă să se abată de la de la morala sa, rămânând fidelă moralei de tip puritan.

Mai mult, ceea ce transpare mai clar decât în primul roman este prolema coruptibilității şi a recăderii în păcat. Este păcătosul mai predispus să păcătuiască din nou sau se poate opri şi se poate reforma? Dacă toată lumea te consideră viciat, mai are sens să îţi păstrezi virtutea? Răspunsul este că se merită şi că virtutea este valabilă prin ea însăşi, independent de lumea în care trăim. Relevanța acestui exemplu de moralitate puritană în lumea de astăzi este că putem rămâne fideli eticii chiar şi atunci când nimeni din jur nu o face. Dacă Clarissa ar trăi astăzi, ar fi la fel de virtuoasă.

Considerăm că acest roman este ilustrarea eticii wittgensteiniene, aşa cum apare ea formulată în prima operă a filosofului.

Wittgenstein (1991) delimitează în Tratatul logico-filosofic ceea ce poate fi spus cu sens de ceea ce poate fi doar arătat. Despre etică, religie, logică, despre limbajul însuşi nu se pot spune în propoziții decât nonsensuri, întrucât limbajul nostru nu permite formularea cu sens decât a propozițiilor descriptive. Etica se arată prin artă (ca în cazul de față). Etica şi valorile sunt 
cu adevărat importante, dar ele se află în afara lumii, privesc lumea ca întreg, şi nu stările de lucruri din ea, care sunt contingente. Recompensa etică stă în fapta însăşi, şi nu în consecințele sale, iar lumea omului fericit este diferită de a omului nefericit (întrucât doar primul poate trăi valorile)

$\mathrm{Nu}$ trebuie să ne imaginăm că lumea faptelor este o sferă, în jurul căreia valorile plutesc. Aceste valori sunt în om, dar într-un om care să fie independent de lumea faptelor (în acest sens în afara lumii faptelor). Toate aceste valori vin din iubire - omul iubeşte cu toată ființa (ființa ca unitate psihofizică, aşa cum apare în cercetări). Iubirea este identitatea omului independent de fapte, singura certitudine, singurul lucru cu adevărat independent de realitate. Din iubire decurg toate valorile după care omul se orientează. Ea determină faptele omului, în orice realitate posibilă. De aceea nu contează starea de lucruri prezentă, pentru că nu starea de lucruri a determinat alegerea unei acțiuni. Aceasta este determinată aprioric.

Aici vedem adevărata importanță a stărilor de lucruri posibile. Lumile posibile (înțelese ca situații contrafactuale, în sensul că stările de lucruri puteau să fie altele) sunt importante pentru etică tocmai prin aceea că valorile iubite rămân aceleaşi, indiferent de starea de lucruri prezentă. Valorile nu sunt alese pe baza faptelor, ele se găsesc dincolo de fapte, în om. Omul etic nu este şi nu poate fi) contingent, prin aceea că faptele pe care le face sunt rezultatul a ceea ce îl călăuzeşte, iar acel ceva rămâne valabil pentru orice situație. Faptele nu sunt făcute în funcție de consecințele pe care la au, ci în funcție de valorile omului. Omul etic nu este produsul experienței, şi nu merge după cum îl poartă soarta (stările de lucruri reale). El modelează această experiență după valorile sale. Omul alege valorile (şi aici importanța voinței, a liberului - arbitru, a faptului că omul alege să se construiască singur, fiind propria lui creație). Omul trăiește faptele în funcție de valorile sale. Iubirea se aplică realității, dar nu are nevoie de ea. Adevărata iubire este absolut dezinteresată (în acest sens lumea omului fericit diferă de cea a omului nefericit). Iubirea înseamnă fericire. Numai omul care iubeşte este cu adevărat fericit. Lumea acestuia diferă pentru că e construcția lui proprie, pentru că se recunoaşte în alegerile sale. De fapt, aceste alegeri sunt singurele pe care le putem controla. Contează felul în care ai ales, şi nu beneficiile contingente.

Valorile nu sunt pur şi simplu ceea ce este mai înalt, ci sunt însuşi omul. Ele decurg din ceea ce iubeşte. Iubirea este singura certitudine, singurul adevăr. Iubirea lui nu e în lume, ci în el. Este la fel de unică ca şi el. Prin ea, omul este propriul lui creator, independent de lume. Temeiul eticii este iubirea, ceea ce decizi să iubești. 
Prin artă iei contact cu un fel de a trăi, cu valorile cuiva, cu un mod de a iubi. Dar omul etic îşi găseşte propriul mod de a trăi, altfel acel om nu ar avea valoare. Principala menire a artei este să fie independentă de lume. Arta adevărată este arta pentru artă, pură imaginație, independentă de orice altceva, independentă chiar şi de creatorul ei. Etica şi estetica sunt acelaşi lucru numai în sensul că există un stil propriu de a iubi, acest stil este estetic. Omul (construcția după acest stil) şi opera de artă (imaginarea altor stiluri) sunt estetice.

Arta lui Richardson este, în opinia noastră, o întrupare a luptei virtuţii şi pricipiilor etice contra contingenței.

\section{Bibliografie:}

Drîmba, O. (2001). Istoria literaturii universale. Ed. Saeculum, vol. II.

Richardson, S. (2003) Pamela. Penguin Books.

Richardson, S. (2004). Clarissa Harlowe or The Story of a Young Lady. Penguin Books.

Wittgenstein, L. (1991). Tractatus Logico-Pbilosophicus. Humanitas. 